\title{
Makineler Film Yapmayı Düşler mi?: Jan Bot Örneği
}

\author{
Batu Anadolu*
}

\section{Özet}

"YeniMedya Sanatı" olarakadlandırılan üretim pratiği; bilgisayar kullanıcllarınınve programlarının sanatsal içerikleri sanal ortamda yaratmaların să̆layan bir yapı oluşturmaktadır. "Yeni Medya Sanatı"nın hesaplanabilir ve algoritmalara dayal yapısı nedeniyle, yapay zeka çalışmaları kültürel alana daha fazla nüfuz etmektedir. Yapay zeka uygulamalarl, sinema endüstrisinde özellikle film yapım, dağıtım ve gösterim alanlarında etkisini hissettirmektedir. Görsel-işitsel anlatılar üretme aşaması içerisinde, sanat felsefesi bağlamında sanat-zanaat ve sanatçı-sanat eseri ilişkileri yeniden tartışmaya açılmaktadır. Bu çalışmada; EYE Film Müzesi arşivindeki görüntülerden kısa filmler üreten Jan Bot isimli yapay zeka uygulamasının çalışmaları incelenecektir. Çalışmanın amacı, Jan Bot'un bir sanatçı olarak biçemsel tercihlerini hermenötik bir yaklaşımla anlamlandırmak ve sanat epistemolojisi ışığında sanatçının kimliğini sorgulamaktır. Jan Bot'un Instagram uygulamasında en çok görüntülenen on filmi, biçem analizine tabi tutulmuştur. Biçem analizi; bir filmi anlatı yapısının yanı sıra ortalama çekim süresi, sinematografik özellikleri, mizanseni, kurgusu ve sesi ile bütüncül bir yaklaşımla ele almayı amaçlamaktadır. Analiz sonucunda; Jan Bot tarafindan üretilen filmlerin biçimsel açıdan şablon özellikler taşıdı ğı ve popüler etiketleri kullanarak alternatif bir anaakım film perspektifi yarattığı tespit edilmiştir. Anlatı açısından ise bu filmlerin, avangart sinemayı hatırlatacak şekilde sanatçı odakl olduğu ve gerçekliğin bir prizmadan kırılarak yansıyan bir yorumunu sunduğu söylenebilir.

Anahtar Kelimeler: Sinema, Yeni Medya Sanatı, Sanat Epistemolojisi, Yapay Zeka, Jan Bot.

ORCID ID : https:/ / orcid.org/ 0000-0002-7420-3818

E-mail : banadolu@live.com

DOI: $10.31122 /$ sinefilozofi. 726799

Geliş Tarihi - Recieved: 25.04.2020

Kabul Tarihi - Accepted: 01.12.2020 


\title{
Do Machines Dream of Making Movies?: The Case of Jan Bot
}

\author{
Batu Anadolu*
}

\begin{abstract}
The production practice called "New Media Art" creates a structure that enables computer users and programs to produce artistic content in a virtual environment. Because of the computable and algorithmic nature of "New Media Art", artificial intelligence studies are more penetrating into the cultural field. Artificial intelligence applications make their impact in the movie industry, especially in the fields of film production, distribution and exhibition. In the stage of producing audiovisual narratives, the relation between art-craft and artist-artwork within the context of philosophy of art is discussed again. In this study; the works of the artificial intelligence application Jan Bot, which produces short films from the images in the EYE Film Museum archive, will be examined. Purpose of the study is to interpret the stylistic preferences of Jan Bot as an artist with hermeneutical approach and to question the identity of the artist in the light of art epistemology. The ten most viewed movies in Jan Bot's Instagram account were subjected to style analysis. Style analysis aims to treat a film with a holistic approach with its narrative structure as well as its average shot length, cinematography, mise en scene, editing and sound. As a result of the analysis, it has been determined that the films produced by Jan Bot have stylistic features and create an "alternative" mainstream film perspective using popular hashtags. In terms of narration, it can be said that these films are artist-oriented in reminding of avant-garde cinema and offer a reflected interpretation of reality by breaking through a prism.
\end{abstract}

Key words: Cinema, New Media Art, Art Epistemology, Artificial Intelligence, Jan Bot.

ORCID ID : https://orcid.org/ 0000-0002-7420-3818

E-mail : banadolu@live.com

DOI: 10.31122/sinefilozofi.726799

Geliş Tarihi - Recieved: 25.04.2020

Kabul Tarihi - Accepted: 01.12.2020 


\section{Giriş}

Manovich (2001: 19); insanlığın tüm kültürünün bilgisayar merkezli bir yapıya kavuşmasını yeni bir medya devrimi olarak nitelemekte ve bu devrimin birçok alanın kesişim noktalarına etki ettiğini öne sürmektedir. Sanatçılar ve uygulama geliştiriciler; "yeni medya sanatı" adı verilen kavram ışığında gün geçtikçe birbirlerine yakınlaşmakta, yeni deneyimlerin üretilmesi konusunda avangart sanatçıların gerçek mirasçılarına dönüşmekte ve nihayetinde modern sanat ile yeni medya, aynı anlatının parçası haline gelmektedir. Bu yeni yaratım ortamı ise kitap sayfaları ya da resim tuvalleri değil, sanal ortam ve ekranlardır.

Sanatçılar ve uzmanlar kadar, onların yaratım sürecinde kullandıkları makinelerin de bir eser yaratma hevesine ve farkındalığına sahip olup olmayacakları günümüzde bir tartışma konusudur. Özellikle yapay zeka alanında yaşanan gelişmeler, sanat epistemolojisi bağlamında sanatçı ve sanat eseri arasındaki ilişkiyi sorgulatmakta ve yeni perspektifler sunmaktadır. Zayıf yapay zekalardan güçlü yapay zekalara geçiş aşamasında ortaya bir bilincin çıkması beklense de; şu anki aşamada özgür irade ile üretilmiş kişisel eserlerden çok, insan deneyimlerini taklit eden bir üretimden söz edilebilmektedir. Sanat eserini anlamlandırma çabası; insanlığın deneyimlerine ve empati duygusuna bağlıyken, bilgisayarın yarattığı eserleri anlamlandırmak da ancak onun deneyimlerini ve referanslarını anlamakla sağlanabilir.

Benzer bir tartışma sinema endüstrisinde de yaşanmaktadır. Günümüzde yapay zeka uygulamaları bizzat içerik üreticileri olarak da karşımıza çıkmaktadırlar. Bu uygulamaların çalışmalarını analiz etmek; sinema endüstrisinin ve çalışanlarının geleceği hakkında düşünmeyi, görsel-işitsel bir hikaye anlatma aracı olarak sinemanın sınırlarını keşfetmeyi ve filmlerle bağ kuran izleyicilerin statülerini gözden geçirmeyi sağlayacaktır.

Bu çalışma kapsamında; Jan Bot isimli bir yapay zeka uygulamasının EYE Film Müzesi' nin veri tabanında yer alan görüntülerden yola çıkarak ürettiği kısa filmler incelenmiştir. Çalışmanın amac1; bir sanatsal ürün yaratıcısı olarak Jan Bot' un nasıl bir üslup belirlediğini ve sinema tarihi içerisinde kendisini nereye yakın konumlandırdığını anlamaktır. Çalışmanın önemi; her geçen gün sinema endüstrisinde kendisine yer edinmeye devam eden yapay zeka uygulamalarının bir film yaratma sürecinde tercihlerinin ne olduğunun sorgulanmasında yatmaktadır. Ortaya görsel-işitel bir ürün çıkaran yapay zeka uygulamalarının, sanat epistemolojisi bağlamında ne ölçüde farklı ya da kişisel bir bakış açısı geliştirebildiği sorusuna cevap aranacaktır. Çalışmanın Jan Bot ile sınırlı tutulmasının nedeni, üç yıla yakın bir süredir her gün film üretmesi ve bu filmleri günbegün sosyal medya hesaplarından yayınlaması nedeniyle benzersiz olmasıdır. Bir yapay zeka uygulamasının ürettiği kısa filmleri, bu kadar uzun bir süre boyunca düzenli biçimde paylaşan başka bir sosyal medya kanalına rastlanmamıştır.

\section{Biçem Analizi}

"Biçem" in kelime anlamı Türk Dili Kurumu sözlüğünde "üslup" olarak verilmektedir (Türk Dili Kurumu, t.y.). İngilizce kelime karşılığ1 "style" olarak verilen biçem; "belirgin bir ifade biçimi", "kendine özgü davranış” ve "bir şeyin yapıldığı, yaratıldı ğı veya gerçekleştirildiği belirli bir yöntem veya teknik" olarak tanımlanabilir (Merriam-Webster Online Dictionary, t.y.).

Sinemada biçem çalışmaları söz konusu olduğunda, ilk olarak filmi oluşturan ögelerin nasıl bir araya geldiği sorusu ortaya çıkar. Bir filmin göze çarpan ilk unsurları; bir anlatı kurmaya yarayan ve çıkış noktası olarak kullanılan hikaye, zaman ve mekan tercihleri olmaktadır. Çok özel veya yaratıcı biçimde kullanılmadıkları takdirde renk, 1şık, kurgu ve ses tercihleri bazen farkına varılmayan unsurlara dönüşebilmektedirler. Bu unsurları fark etmek ve tanımlamak, biçemsel analizin başlangıç noktası olabilmektedir. Göze çarpan tekniklerin belirlenmesi ile bu tekniklerin, tekrar eden düzenli yapılar oluşturup oluşturmadığ 1 fark edilecektir. Biçemsel örüntülerin filmin anlatısını ya da dramatik gelişmeleri güçlendirmek amacıyla vurgulanması 
bir tercih olabilmektedir. Analiz yapan kişi, biçemin filmin genel formunda oynadığı rolü inceler. Bu noktada biçemi oluşturan ögeleri genel bağlam dişında incelemekten kaçınmak gerekmektedir (Bordwell ve Thompson, 2008: 306-309).

Bordwell (1997: 4) film biçem analizini anlatısal ve biçimsel olarak beş başlıkta inceler: Anlatı yapısı, sinematografi, mizansen, kurgu ve ses. Biçem, en basit manada filmin yaratıcısının tarihsel koşullar bağlamında yaptığı seçimlerinin sonucudur. Bununla birlikte kişisel (belirli bir yönetmene has) ve genel (belirli bir döneme veya okula ait) biçem tercihlerinden de söz edilebilir.

Bir diğer biçem sınıflandırması ise üç başlığa ayrılmaktadır: Realizm, Klasisizm ve Biçimcilik (Giannetti, 2014: 4). Bu yaklaşıma göre gerçekçi ve biçimci yaklaşımlar belgesel ve avangart türler üzerinden anlamlandırılan iki ucu temsil ederken klasik yaklaşım bu iki ucun uylaşım noktasında yer almaktadır. Üç başlık arasında net bir ayrım yoktur, geçişlilik ve birbirinden beslenme söz konusudur.

Bu çalışmada; Jan Bot tarafından üretilen ve 06.10.2017-13.02.2020 tarihleri arasında Instagram hesabında yayınlanan filmler arasından en çok görüntülenen on tanesi, biçem analizine tabi tutulmaktadır. En az 1673 en fazla 75 bin kez izlenen bu filmlerin anlatısal ve biçimsel özelliklerin ne gibi benzerlikler gösterdiği araştırılmaktadır. Bordwell'in belirlediği beş yaklaşım -anlatı yapısı, sinematografi, mizansen, kurgu ve ses- üzerinden filmler analiz edilmiş, ek olarak kültürel ve teknolojik değişimler ile yıllar içerisinde farklılık gösteren “ortalama çekim süresi” de gözlemlenmiştir. Bu yaklaşımlar, Giannetti' nin sınıflandırmasıyla iç içe incelenmiştir. Biçem analizinin tercih edilmesindeki neden; belirli bir veri tabanını kullanan ve daha önce gözlemlenmemiş bir anlatı ve biçim dünyası ortaya koyan Jan Bot'un filmlerinin belirli düzenler ve örüntüler içerip içermediğini sorgulamaktır. Biçem analizi bu açıdan anlatısal ve biçimsel bir bütüncül yaklaşım sağlamaktadır.

\section{Yeni Medya Sanati}

Yeni Medya Sanatı'nı tanımlama çabası, 1960'1 yıllara uzanmaktadır. Elektronik sanat, multimedya sanatı, interaktif sanat, sanal sanat ve siber sanat gibi tanımlamalar yapılmış olsa da yeni medya sanatı adlandırması; sanatın etkisini basım-yayın, uydu, video, televizyon gibi birçok gelişen teknolojiye yansıtması nedeniyle tercih edilir olmuştur (Quaranta, 2013: 23). Yeni medya sanatının aynı zamanda bir bilgisayar sanatı olduğu söylenebilir. Bilgisayar sanatı; sanatçıları, bilim adamlarını, teknoloji uzmanlarını ve matematikçileri tek bir aracın karşısına toplamayı başarmış ve farklı perspektiflerin bu sanatın başlıca karakteristiklerini, artistik amaçlarını ve disiplin normlarını belirlemesini sağlamıştır (Taylor, 2014: 11). Sonuç olarak yeni medya sanatı; resim, heykel, fotoğraf, film ve enstalasyon gibi sanat formlarını simüle eden ve bu kategoriler arasındaki bir zamanlar var olan kutsal ayrımları ortadan kaldıran dağınık bir kavramdır.

Yeni medya sanatı sadece sanat ürününün ortaya çıkarılmasında değil; sergilenmesinde, anlamlandırılmasında ve arşivlenmesinde de önemli rol oynamaktadır. Herhangi bir ulusal mirasa ya da merkezi bir lokasyona bağlı kalmayan bilgisayarlaşma, yeni medya sanatının daha az kestirilebilir ve kalıplara sokulabilir olmasını sağlamaktadır (Taylor, 2014: 11). İnternetin küresel olarak yaygınlaşması ve bilgisayarların daha ucuz hale gelmesiyle içerik üretimi, uzmanlardan sıradan kullanıcılara uzanan geniş bir kitlenin imkanları dahilindedir. Etkileşim özelliği ve açık kaynak adı verilen katılımcı üretim yöntemi, izleyicinin sanat eseriyle iletişim kuran ya da onu yeniden oluşturan bir güce kavuşmasını sağlayabilmektedir (Graham, 2014: 6). Böylece sanat eserinin oluşumunda sanatçıdan izleyiciye uzanan hiyerarşik yapı ortadan kalkabilmektedir.

İnternetin bir kitle-pazar iletişim aracına dönüşmesi ile yeni medya sanatı, toplumlar ve kültürler üzerindeki etkisini artırmaktadır (Tribe ve Jana, 2006). Metin, resim ve video dosyalarının işlenmesinin ve değiştirilmesinin kolaylaşmasıyla; yeni medya sanatının kapsamı 
en iyi ve güzeli yaratmaktan çok, en pratik ve ucuza mal edilebilir ürünün yaratılmasına evrilmektedir. Bunun sonucunda sanatçının ve sanat eserinin toplumdaki yeri konusunda birtakım sorgulamalar da ortaya çıkmaktadır.

Yeni medya sanatı; bilgisayarların sanatsal üretim sürecinde kullanılması dolayısıyla makinelerin sınırları üzerine düşünmeye yönelik bir alan açmaktadır. Kullanıcıların yanı sıra makinelerin de bir sanatçı özelliği taşıyıp taşımadığı sorusu akıllara gelmektedir. 1950'li yıllarda bilgisayarlar ticari reklam tasarımlarında kullanılmaya başlanmıştır. Bu dönemde yapay zeka henüz ilkel bir yaklaşımla ele alınmış olsa da; katot ışınlı tüplerin kullanımı ile makine kodları ve diğer giriş/çıkış işlemleri okunabilir türde görüntülenmiş ve böylece dil arayüzlü makineler olarak bilgisayar kavramı güç kazanmıştır. Bugün tasarımcının rolü; çoğunlukla endüstriyel tasarım, grafik kullanıcı arayüzleri, kullanıcı deneyimi ve veri görselleştirme alanlarına kaymıştır. Sanayi için sanat, mühendislik ortamıyla bütünleşmektedir (Prelinger, 2015: 269). Bilgisayarlar ise bu süreçte güçlü bir araç olarak nitelendirilmekte fakat gerçek bir yaratıcılıktan da uzakta tanımlanmaktadır. Örneğin; bir sanat eseri oluşturmak için işlem yürüten bir bilgisayara sahip olmak, bir müzik parçası düzenlemek veya aynı formülün sayısız varyasyonunu takip etmek için zar atmaktan farklı değildir (Penha ve Carvalhais, 2019). Yapay zeka ve sanat ilişkisinde var olan sorulara yenilerinin eklenmesinde sanat felsefesindeki tartışmaların rolü önem taşımaktadır.

Yeni medya sanatının sinema ile olan ilişkisi, dijital sinema kavramı ile yakından ilişkilidir. Özellikle 1990'l y yllardan itibaren görsel efektler ve dijital sinematografi araçları üzerinden kullanılan bu kavram; günümüzde sinema ile izleyici arasındaki ilişkiyi dönüştüren bir yapıyı ortaya çıkarmaktadır. Görüntünün dijitalleşmesi ile kareler birer veriye ve koda dönüşürken; bu veri ve kodların taşınması, zamandan ve mekandan bağımsız gösterilmesi ve manipüle edilmesi mümkün hale gelmektedir (Manovich, 2001: 263). Geleneksel kültürel formların dönüşümü, sinema alanında yapım, dağıtım ve gösterim metotlarının değişimi ile sonuçlanmaktadır. Yapım sürecinde dijitalleşme; film yapım modları arasındaki ayrımları azaltmış, masrafların kısılması ile araçların kullanımı demokratikleşmiştir (Culkin, 2008: 45). İçeriklerin dijital platformlarda ve sosyal medya araçlarında yer alması ile uzmanlaşma kavramı muğlak hale gelmektedir. Görüntülenme sayısı üzerinden ticari bir değer kazanan görsel-işitsel içerikler, bir meta değeri edinmenin yanı sıra diğer içerikler için öncü konuma gelerek yeni medya sanatı içerisinde bir devamlılık oluşturmaktadır.

Diğer taraftan dijital görüntülerin korunması, restorasyonu ve arşivlenmesi açısından dijital veritabanları öne çıkmaktadır. Bu görüntülerin dijital araçlardan sergilenmesi, hem daha fazla izleyiciye ulaşma hem de görüntüleri dönüştürme ve farklı içeriklerde kullanma yolunu açmaktadır (Matthau, 2015). Dijital sinemanın yeni anlatılar kurmayı kolaylaştırması ile sinema tarihi içerisinde Noel Burch'un kurumsal ve primitif temsil biçimleri ${ }^{1}$ olarak tanımladığı yaklaşımlar yeniden tartışılır hale gelmektedir. (Burch, 1990). Sinema endüstrisine hakim olan kurumsal temsil biçimine karşın, dijital sinema aracılığıyla yeni medya sanatı içerisinde arşiv görüntüleri üzerinden bir meydan okuma çabası gözlemlenmektedir. Dünyanın her köşesinden gelen ve belirli bir kültüre ya da geleneğe indirgenemeyecek film parçaları; kapalı ya da klasik anlatıyı reddeden, kurumsal temsil biçiminin doğrusal ve sıfır noktası yaklaşımına² karşıt bir düşünce içerisinde, kesmeler arasındaki uyumu göz

\footnotetext{
${ }^{1}$ Kurumsal temsil biçimi (KTB-Institutional mode of representation), 20. yüzyılın başından itibaren gelişen ve yaklaşık olarak 1914 'te norm haline gelen baskın film yapım tarzıdır. Bugün üretilen hemen hemen tüm filmler KTB içinde yapılsa da, tek temsil biçimi bu değildir. Diğer temsil biçimini KTB'ye karşı yapısökümcü bir yaklaşım getiren, genellikle Batılı sinemanın dışında aktif olan ve 1. Dünya Savaşı sonrasında Amerikan sinemasının hakimiyeti öncesinde yaygın olan primitif temsil biçimi (PTB-Primitive mode of representation) oluşturur. KTB`de perdede tamamen kapalı bir kurgusal dünya yaratma girişimi gözlemlenir ve temelleri atılan sinema dili ile, izleyici filmle arasına mesafe koymak yerine tamamen hayal gücüyle meşgul olur. Primitif temsil biçiminde ise sinemanın yarattığı büyüyü yıkar ve evrensel sinema dilini bozarak kurumsal yaklaşıma bir karşıtlık oluşturur (Burch, 1990). 2 Sıfır noktası yaklaşımı ya da zero point of cinematic style: Sinemanın özellikle sesin de gelişinden sonra özünde gerçekçi bir aktarım aracı olarak kabul edilmesi ve bu gerçekliğin yaratılması amacıyla çekim ve kurgu tekniklerinin rafine biçimde kullanılmasıdır. Burch'a göre bu yaklaşım, kurumsal temsil biçimini mükemmelleştirirken yaratıcı anlatım biçimlerini ve sinemanın olanaklarını kısıtlamaktadır (Burch, 1981: 11).
} 
ardı eden ve özdeşleşmeyi mümkün kılmayan anlatılar oluşturarak primitif temsil biçimine yakın durmaktadırlar. Özellikle 1. Dünya Savaşı'ndan sonra kurumsal temsil biçimi sinema endüstrisine hakim olmaya başlasa da; yeni medya sanatı, bir bakıma sinemayı yeniden keşfe çıkarak primitif dönemi geri getirmektedir.

\section{Sanat Felsefesi Bağlamında Yapay Zeka}

Yapay zeka; "Doğal sistemlerin yapabildiği her bilişsel etkinliği yapay sistemlere, daha da yüksek başarım düzeylerinde nasıl yaptırabileceğimizi inceleyen bir bilim dalıdır" (Say, 2018: 83). Doğal sistemler benzetmesi, insan beyninin çalışma prensibine yakın veya onu taklit eden bir yapıyı işaret etmektedir. Yapay zekanın "akıllı davranış otomasyonu" (Luger ve Stubblefield, 1998: 1) olarak nitelendirilmesi ise insan zihninin taklit edilmesine karşın, kesinliğe dayalı rasyonel sonuçların alınmasının hedeflendiğini göstermektedir. $\mathrm{Bu}$ bağlamda yapay zeka çalışmalarında hedef, bilgisayarların bir işi insanlardan daha iyi yapıp yapamayacağını incelemek ve bu alanda sınırları zorlamaktır (Nilsson, 1998: 1-2).

Yapay zeka çalışmalarında dönüm noktası, insan beynine yakın bir yapı kurularak yapay sinir ağlarının birbirleriyle iletişim kurmasının sağlanmasıdır. Yapay sinir ağlarındaki girdi ve çıktı katmanları, algoritmalar ve derin öğrenme teknolojileri aracılığıyla yapay zekanın eğitilmesini ve bir işi gün geçtikçe daha iyi yapmasının sağlanmasını hedeflemektedir. Bunun sonucunda yapay zekanın zamanla farklı girdilerle karşılaştığında önceki deneyimlerine dayanarak uygun bir çıktı vermesi beklenmektedir (Say, 2018: 105).

Russell ve Norvig (1995:9)'e göre; felsefedeki yapay zeka tartışmalarının geçmişini, Descartes' ten yola çıkarak düalist yaklaşım ve bu yaklaşım karşısında konumlanan materyalist yaklaşım tartışmasına taşımak mümkündür. Descartes; 17. yüzyılda zihin ve madde arasındaki ayrım üzerine düşünmüş ve tamamen fiziksel bir zihin anlayışının, özgür iradeye çok az yer bıraktığını savunmuştur. Bu nedenle insanın; doğanın dışında, her şeyden muaf bir parçası vardır. Bu düalist yaklaşım, insan dışındaki canlıları kapsamamaktadır. Düalizmin karşısındaki materyalist anlayışa göre ise; tüm dünya fiziksel yasalara göre işlemekte ve zihin de bu fiziksel yasalar içerisinde temellendirilmektedir. Bu iki yaklaşımın ortasında ise bir uzlaşı sunulabilir: Zihinsel süreçler ve bilinç, fiziksel dünyanın bir parçasıdır ama doğası gereği bilinemez ve rasyonel anlayışı ötesinde özellikler gösterebilmektedirler.

Nilsson (2010: 449) ise; bilişsel bilim ve yapay zeka arasındaki ilişkinin, yapay sinir ağlarının anlamsal ağlar olarak nitelendirilmesi yoluyla kurulduğunu ve ağların kendi içerisinde taksonomik (sınıflandırılmış) hiyerarşi meydana getirdiğini ifade etmektedir. Bu hiyerarşiler "ontoloji" olarak nitelendirilmektedir. Yapay zeka çalışmalarında ontolojiler; birtakım konseptler çerçevesinde ilişki setleri içermektedirler. Her ilişki seti, birer varoluş noktası oluşturmaktadır. Varoluşsal hedefler ve bu hedefleri yerine getirme yolları üzerinden bakıldığında ise yapay zeka çoğunlukla materyalist felsefe ışı̆̆ında incelenmiştir. Yapay zeka uygulamaları; insan davranışlarını taklit ederek komplike görevleri mümkün olduğunca mükemmel biçimde yerine getirme amacıyla kullanılmaktadır. Bu görevler yapay zeka tarafından sorgulanmadan yerine getirilmektedir ve yapay zekanın özgür iradeye sahip olarak kendi bilincini ortaya koyması beklenmemektedir. Searle (1980: 418) bu yapay zekaları "zekice hareket edebilen bir fiziksel sembol sistemi" olarak nitelendirmekte ve "zayıf yapay zeka" adını vermektedir. Zayıf yapay zeka yaklaşımında Descartes'in düalist yaklaşımın dışında tuttuğu diğer canlılara benzer şekilde, makineler de özgür iradeye sahip değildir.

Nilsson'un (2010: 662) “İnsan Düzeyinde Yapay Zeka” olarak adlandırdığı yaklaşımda insanın zeki davranışlarını taklit etme düşüncesi temel oluşturmaktadır. Her ne kadar insanların her davranışının otomatikleştirilmesi şu an mümkün olmasa da ekonomik ve bilimsel nedenlerden ötürü bu çalışmalar devam etmektedir. Bilimsel nedenlerin en önemlisi; insan beyninin çalışma prensiplerinin çeşitli hesaplama modelleri ile tekrardan yaratılıp yaratılamayacağıdır. Bu çabaların bizi "güçlü yapay zeka" yaklaşımına taşıması kaçınılmaz gibi görünmektedir. Bu yaklaşımda "fiziksel sembol sistemleri bir akla ve zihinsel yapılara 
sahip olabilmektedir" (Searle, 1980: 418). Kaplan ve Haenlein (2019: 16) bir üçüncü basamak olarak "bilinçli/öz farkındalığa sahip yapay zeka"yı göstermektedirler. Bu yapay zeka, hemen her alanda insandan daha üstün bir performans gösterecektir. Böylece insanı diğer canlılardan ayıran "özgür irade", "eyleyici edimlerin özgür iradeyi çözümlemesinin ve ortaya çıkarmasının makine zekasında modellenebilmesiyle elde edilebilir" (Zambak, 2018: 181).

Yapay zeka çalışmalarındaki gelişmeler, felsefe ile pozitivist bilimler arasındaki sınırları da kaldırmaktadır. İnsan aklından bağımsız bir düşünce biçiminin ve tasnifleyici mantığın ortaya çıkma ihtimali, yeni bir epistemolojik yaklaşım gerektirmektedir (Doğrucan ve Hazar, 2019: 160). Kendi içerisinde mükemmel bir yapının insan süzgecinden geçemeyeceği bir durumda mantıksal ve rasyonel olanın tanımlanması da imkansız hale gelecektir. Benzer bir yaklaşım, sanat alanında da söz konusudur. Yeni medya sanatı içerisinde yapay zeka denemeleri, farklı bir mantık ve estetik üzerinden ortaya çıkardıkları eserler ile izleyicileri şaşırtmaktadır.

Sanat epistemolojisi, genel olarak sanat ile bilgi arasındaki ilişkiye odaklanmaktadır. Sanatın, bilginin kaynağı olup olmayacağı ve bilişsel değeri sorgulanmaktadır (Taşdelen, 2012). Antik çağlarda sanat; daha çok bir zanaat olarak ele alınmış ve sanatçılar, el ile çalışan insanlar grubunda sayılmıştır. 18. yüzyıldan itibaren ise sanatın modernite çerçevesinde "entelektüel bir faaliyete" dönüştüğüu söylenebilir (Balc1, 2019: 3). Sanatın kazandığı bu yetkinlik, onu topluma ve insan duygularına 1şık tutan bir araca dönüştürmektedir. Sanat eseri yaratıcısının elinden çıkarak bizim dünyaya olan bakışımız çerçevesinde anlayışımızı değiştirebilmekte ve doğal olarak izleyen kişinin farklı bir insan haline gelmesine neden olabilmektedir. Diğer taraftan sanat eseri, sanatçının kendini ifade etme ve dünyayı algılayış biçimlerinin yansıması olarak da görülebilmektedir (Kirilenko ve Korshunova, 1987: 38-40). Sanatçı eserini meydana getirirken fiziksel dünyayla iletişim kurmanın yanı sıra, kendi ruh dünyasını da bir kaynak olarak kullanma yolunu seçebilmektedir. Bu durumda sanatçının kişisel imzasını da atarak özgür iradesiyle eserler ürettiği ve zihinsel süreçler ile fizik yasaları arasında bir uyum yakaladığı söylenebilmektedir.

Yeni medya sanatının ortaya çıkışı, sanat-zanaat ilişkisini yeniden güçlendirmektedir. Sanatın duyulardan ortaya çıkan ve yine duyulara hitap eden yapısıyla birlikte Platon'un matematiksel ölçülere ve simetriye dayalı formel estetiği arasında bir ikilem söz konusudur. Sanat eserinin yaratılması sürecinde mühendislerin, programcıların üretime katılması ve elde edilen ürünlerin ekonomik ve bilimsel temelli çalışmalara olan katkısı düşünüldüğünde "tekhne kavramından yola çıkan sanat-zanaat birlikteliği güçlenmektedir" (Ülger, 2013: 2526). Algoritmalara, derin öğrenmeye ve veri tabanlarına bağlı sanat eserleri üretebilen yapay zekalar, sanatçı kavramını yeniden sorgulamaya açmaktadır. Sanatçının geleneksel bir bakış açısıyla "sanat eseri yaratımına bilinçli olarak katkıda bulunan kişi" (Dickie'den aktaran Taşdelen, 2012) olarak tanımlanması, yapay zeka uygulamalarının eser yaratımında ne ölçüde bilince ve özgür iradeye sahip olduklarını tartışmaya açmaktadır. Çağdaş sanat yönünden ise sanatçılığın kapsamı "vizyonumuzu yenileyen ve dünyayı yeni şekillerde görmemize yardımcı olan" (Getlein, 2009: 10) kişi -ya da makine- olarak genişletildiğinde yapay zeka uygulamaları da kendisine yer bulabilmektedir

Yapay zekanın orijinal bir eser üretip üretemeyeceği veya yaratıcı biçimde davranıp davranamayacağısorularını Turing (1950:441-450), "makinenininsanışaşırtıp şaşırtamayacağı" sorusuna indirgemektedir. Bu indirgeme sonucunda ise makinelerin yaratıcı davranışlara sahip olabileceğini iddia etmektedir. Bu düşüncenin arkasında bilgisayarların astronomik olarak farklı şekillerde davranabileceği fikri yatmaktadır. Kaplan ve Heinlein (2019: 19) ise yapay zeka alanında yaşanan büyük gelişmelere rağmen sanatsal yaratıcılık alanında insanların hala üstünlüğünü koruduklarını iddia etmektedirler. Yapay zeka sanat alanında ya da eğlence sektöründe bir problem çözücü olarak kullanılsa da, içerik üretmede ve sanatçı bilinciyle yaklaşım hususunda sorunların çözülmesi şu an için olası görünmemektedir. 


\section{Bilgisayarlaşma, Yapay Zeka ve Sinema}

1970'li yıllarda videonun yaygınlaşması; televizyonun zaman ve mesafe anlayışı üzerinde yaptığı değişikliklerin de etkisiyle film estetiğini anlamlandırma çabasında yeni düşüncelere neden olmuştur. Youngblood (1970: 41); "genişletilmiş sinema" kavramını ortaya atarak film özel efektleri, bilgisayar sanatı, video sanatı, çoklu ortamlar ve holografi gibi yeni teknolojilerin arasındaki sınırların kaybolduğunu iddia etmektedir. 1980'li yılların başında yönetmen Francis Ford Coppola' nın sinema ve televizyonda üretim pratiklerini sentezleyerek bir "elektronik sinema" yaratma çabası, film üretiminin dijital ve taşınabilir ekranlara taşınmasıyla sonuçlanmıştır. Bu tarihten günümüze değin bilgisayar üretimli imgeleme, sürekli yenilikçi arayışların merkezi haline gelmiştir. Film yapım pratiklerindeki değişimle internet, video ve televizyon yayıncılığı da sinemanın kolektif tanımı içerisinde kendisine yer bulmaktadır (Gürkan, 2016: 164). Dijital film üretimi; ekipte daha az kişinin yer almasını, daha hafif ekipman kullanılmasını ve daha az para harcanmasını sağlamaktadır (Ganz ve Khabib, 2006, s. 24). Üretimde olduğu gibi film tüketiminde de farklı araçlar ve kanallar ortaya çıkmakta, film izleme bir kişisel örgütlenmeye ve sosyal bir ağ içerisinde dişavurumsal bir edime dönüşmektedir (Casetti, 2011, s. 89).

Farklı kanallar arasındaki uyumluluk, sinemayı ve film yapma sürecini neredeyse yeniden tanımlamayı gerektiren bir sinema öncesi dönemi hatırlatmaktadır (Stam, 2000: 326). Birçok yaratım potansiyelinin ortaya çıkması, yeni kırılmalara yol açmaktadır. Bugün sinema alanındaki bu kırılmanın en önemli unsurlarından biri, algoritmalar ve veri tabanları aracılığıyla yapay zekanın yaratıcı kullanımıdır. Yapay zeka ile sinema alanının etkileşiminin artmasında iki unsur göze çarpmaktadır: Bu unsurların ilki, yapay sinir ağlarının yapılarının çözümlenmesi ve algoritmalar aracılığıyla çeşitli görevlere tabi tutulabilmesidir. Diğer gelişme ise yapay sinir ağlarını eğitecek veri tabanlarının varlığıdır.

Algoritmalar; semboller, harfler, kelimeler ve rakamlar gibi tanımlanmış matematiksel bileşenlerin belirli görevleri bir "makine" gibi yerine getirmesini temsil etmektedir. Bilgisayar sistemlerinde algoritmalar, belirli bir donanım ve yazılım ortamında tanımlı işlemlerin yürütülmesini mümkün kılan bir kodda uygulanan özyinelemeli yordamları tanımlar (Goffey, 2008: 15-20). Algoritmaların matematiksel operasyonel kural setleri, sanat alanında yaygın olarak bilgisayar sanatı veya dijital sanat olarak tanımlanan kültürel ve teknik uygulamanın temelini oluşturur. Algoritmik tabanlı sistemler; görüntüler üretebilir, tasarım nesneleri oluşturabilir, makine etkileşimlerini kontrol edebilir ve şekillendirebilir. Algoritmaların çalışması ve sembolik verileri işlemesi insanın duyuları tarafından direkt olarak gözlemlenemez, ancak bağlı olan cihazlardaki etkileri üzerinden deneyimlenebilir. Bu nedenle belirsizlik ve otomatizm, bilgisayar temelli sanatın temel özelliğidir (Broeckmann, 2016: 89-90).

Veri tabanı (database) ya da elektronik veri tabanı ise bir bilgisayar tarafından hızlı arama ya da erişim için özel olarak organize edilen herhangi bir veri ya da bilgi koleksiyonudur. Veri tabanları; çeşitli veri işleme çalışmalarıyla birlikte verilerin depolanmasını, alınmasını, değiştirilmesini ve silinmesini kolaylaştırmak için yapılandırılmıştır (Encyclopedia Britannica, 2020). Bir veri tabanı genellikle bilgisayarlı bir kayıt tutma sistemi olarak anlaşılsa da; esasen bir kütüphane veya arşiv gibi "veri konteynerleri” ne sahip, yapılandırılmış bir veri topluluğudur. Her veri konteyneri; sanal ve dinamik veri alanlarından farklı özellikler gösterse de kendi başına bir veri alanı ve bilgi mimarisi oluşturur (Paul, 2007: 95). Veri tabanlarında yer alan veriler, çeşitli bölümlere ve dallara ayrılabilir ve bu dallar arasındaki ilişkiler düzenlenebilir. Anahtar kelimeler ve çeşitli sıralama komutları kullanılarak, kullanıcılar belirli veri kümeleri hakkında rapor almak veya rapor oluşturmak için birçok kayıttaki alanları hızlı arayabilir, yeniden düzenleyebilir, gruplandırabilir ve seçebilir.

Veri tabanı, bilgisayar çağında yaratıcı sürecin merkezi haline gelmektedir. 1980'lerde yüksek teknoloji alanları, analog ve dijital sistemler arasında bir değişim de dahil olmak 
üzere görsel bilgilerin çeşitli şekillerde işlenmesine izin veren farklı multimedya formatları ile birleşmiştir (Taylor, 2014: 187). Sanat, giderek esnek bir veri tabanı veya veri yapısı olarak nitelendirilmeye başlanmıştır. İlişkisel veri tabanları kavramı gittikçe kültüre sızmaktadır. Sanal dünya bize sonsuz sayıda yapılandırılmamış resim, video ve metin sunmaktadır. Bunların anlamlı bir düzleme oturtulması, veri tabanları ile modellendirilmesine bağlıdır. Sürekli olarak yeni ögelerin eklenmesi, internetin anti-anlatı mantığına katkıda bulunmakta ve içerikleri birer hikayeden çok koleksiyona dönüştürmektedir. Anlatı örtük, veri tabanı ise açık bir yapıya sahiptir.

Yukarıda bahsi geçen gelişmeler ile yapay zeka, kültür ve eğlence alanında da etkin hale gelmektedir. Edebiyat, müzik ve oyun alanlarında yapay zeka, pek çok görevi başarıyla yerine getirmekte ve insan aktivitelerine yardımcı olma pozisyonunun ilerisine geçmektedir. Google'a bağlı bir yapay zeka takımı olan Deepmind, Çin kökenli bi strateji oyunu olan Go' nun en iyi oyuncularından biri olan Güney Koreli Lee Sedol'ü 100-0 mağlup eden AlphaGo'yu yaratmışlardır. Yine aynı ekip 49 video oyununu kendi başına öğrenip diğer oyunculardan çok daha iyi sonuçlar alabilen bir bilgisayar yapmışlardır (Clark, 2015). ABD'li müzisyen Taryn Southern' in 2018' de piyasaya çıan "I AM AI" isimli albümündeki tüm besteler yapay zeka tarafından hazırlanmıştır (Plaugic, 2017). Sanatçı ve eğitmen Bager Akbay, Deniz Yılmaz mahlasıyla şiirler yazan bir "robot şair" yaratmıştır (Akbay, 2015). 2016 yılında ise Japonya' nın Future Üniversitesi'nden bir ekip, yapay zeka ile ortaklaşa kaleme aldıkları "Bir Bilgisayarın Roman Yazdığı Gün" (The Day A Computer Writes A Novel) isimli kısa öyküleriyle yerel bir edebiyat ödülleri yarışmasında üst tura çıkmışlardır (Shoemaker, 2016).

Sinema alanındaki yapay zeka çalışmaları daha çok var olan işlerin düzgün biçimde yapılması, işlem süresinin ve maliyetlerin düşürülmesi amacıyla kullanılmaktadır. Warner Bros'un Cinelytic ile imzaladığı anlaşmada olduğu gibi projelere yeşil 1şık verilmeden önce verilere ve tahminlere dayalı öngörüler değerlendirilmektedir. İzleyici tercihlerinin ve beklentilerinin ölçülebilir verilere dönüştürülmesi ile senaryolarda değişiklikler yapılmakta ve senaryo/gişe başarısı denklemi kurulmaktadır. Epagogix ve Scriptbook gibi firmalar bu alanda çalışmalarını sürdürmektedirler (Avcıoğlu, 2017: 110).

Yaratıcı içerik üretiminde ise IBM tarafından geliştirilen "Watson" isimli yapay zekanın çalışması önemli bir başlangıç noktasıdır. Watson yüzlerce korku korku filmine ait fragmanların görsel, işitsel ve yapısal analizini gerçekleştirmiş ve 90 dakikalık Morgan (Luke Scott, 2016) filmini tarayarak fragmana eklenecek sahneleri belirlemiştir. Bu işlem sadece bir günde tamamlanmıştır (Smith, 2016). Görsel analiz yapılırken belirlenen farklı duygu kategorileri ile yapay zekaların, görsel-işitsel içerik üretiminin bir sonraki aşamasında kendi senaryolarını yazmaları ve filmlerini çekmeleri şaşırtıcı değildir. Benjamin isimli bir yapay zeka tarafından yazılan Sunspring (Oscar Sharp, 2016), It's No Game (Oscar Sharp, 2017) ve hatta yönetilen Zone Out (2018, Benjamin) gibi filmler aracılığıly anlatının ve film yapımının sınırları zorlanmaktadır. Benjamin'in sahip olduğu belleğe yüzlerce film içeren bir veritabanı yüklenmiş ve bir cümlelik komut verilmiştir. Benjamin bu komut üzerine ilişkilendirdiği kelime öbeklerini ayrıştırarak senaryo formatında bir içerik üretmiştir, bir de film şarkısı yazmıştır (Carter, 2018).

Benjamin her ne kadar bir veri tabanı üzerinden içerikler üretiyor olsa da; sahne direktiflerini belirleme ve anlam yaratma becerisi açısından kendine has bir dil oluşturmayı başarmıştır. Ayrıca senaryo yazım süresinin ve harcalamalarının oldukça kısılmış olması, gelecekte yapay zeka uygulamalarının yaygınlaşmasının yolunu açmaktadır. Dijital platformların yaygınlaşması ile bu filmler daha fazla görünür kılınmakta ve özellikle Hollywood'un içinde bulunduğu yaratıcılık krizine yönelik bir çözüm ışı̆̆ı ortaya çıkmaktadır (Anadolu, 2019: 53-54). 


\section{Jan Bot}

Jan Bot; Hollanda' nın Amsterdam şehrinde yer alan EYE Film Müzesi, Creative Industries Hollanda Fonu ve Amsterdam Sanat Eserleri Fonu (AFK)'nın destekleri ile yaratılmış ilk film yapım robotudur. Jan Bot, film yapımcıları Bram Loogman ve Pablo Núñez Palma tarafından iki kaynaktan beslenerek deneysel videolar yapması için programlanmıştır. Kullanılan kaynaklar; EYE Film Müzesi'nin Bits \& Pieces adı verilen buluntu filmler veri tabanı ve internette yer alan günlük çok konuşulan konulardır (trending topics). Bu konular; internette en çok kullanılan anahtar kelimeler ve etiketler üzerinden listelenmektedir (Loogman ve Palma, 2018).

EYE Film Müzesi'nin buluntu film veri tabanının oluşturulması 1989 yılına dayanmaktadır. Var olan filmler herhangi bir yönetmene ya da film okuluna atfedilemeyen içeriklere sahiptir. Filmlerin büyük çoğunluğu sinemanın ilk otuz yılına (19. yüzyıl sonundan 1920'li yıllara) dayandırılmaktadır. 2020 yılı Eylül ayı itibarıyla arşivde 600'den fazla film parçası yer almaktadır ve film sayısı günlük olarak artmaktadır. Filmlerin arşive eklenmesinde ve korunmasında sübjektif bir yaklaşım söz konusu olmaktadır. Kuratörler filmleri "ilginçliklerine, tuhaflıklarına ya da sürprizli içeriklerine göre" tercih etmektedirler (Olesen, 2013). Görüntülerin çevrimiçi aktarılabilmesi de önemli bir kıstastır.

Jan Bot günde ortalama yirmi film üretmekte ve bu filmlerden seçtiği bir tanesini Instagram, Twitter ve Facebook sosyal medya kanallarında yayınlamaktadır. Özetle Jan Bot'un iki şey yaptığı söylenebilir: İlki, çevrimiçi medyanın estetiğini keşfederek ve algoritmaları birer kurgu aracı olarak kullanarak deneysel film yapımında yeni bir metot oluşturmaktır. İkincisi ise çevrimiçi ortamlar aracılığıyla görsel-işitsel mirası sunmanın orijinal bir yolunu bulmaktır (Palma, 2018).

Jan Bot'un çalışma prensibi altı başlıkta özetlenebilir (bkz. Tablo 1). Bu başlıklar sırasıyla; kaynak materyalin tanımlanması, meta verinin oluşturulması, kaynak materyalin seçilmesi, bir filmin oluşturulması, filmin yayınlanması ve izleyiciye ulaşmasıdır (Loogman ve Palma, 2018).



Tablo 1: Jan Bot'un Çalışma Prensibi (Loogman ve Palma'dan hareketle)

Kaynak materyalin tanımlanması aşamasında; Bits \& Pieces veri tabanındaki filmler çekim tanıma (shot detect) isimli algoritma ile kesmelere bölünürler. Bu bölme işleminde çerçevede yer alan her pikseldeki değişimler belirlenir ve çekimler sınıflandırılır. Jan Bot sekiz yüz bin çerçeveyi birbirleriyle kıyaslamaktadır. Meta verinin oluşturulmasında Jan Bot, Computer Vision isimli bir teknolojiyi kullanarak çekimleri etiketlendirir. Etiketlendirme teknolojisi için Clarifai isimli bir görsel tanıma yazılımından yararlanılır. Kaynak materyal seçilirken Google Trends üzerinden güncel çok konuşulan konular ve ilgili haberler kullanılmaktadır. Cortical isimli bir doğal dil işleme programı aracılığıyla kelimelerin çoklu anlamları analiz edilerek Jan Bot'un etiketleri ile trendler arasında bağlantı kurulmaktadır. Mükemmel uyum sağlayan eşleşmeler filmde yer almaktadır. Bu mükemmel eşleşme; bazen "rock müzik" ile İngilizce "kaya" anlamina gelen "rock" kelimesinin eşleştirilmesi gibi fazlasıyla edebi kalabilmektedir. Kesinliğe dayalı bu tercihler olduğu gibi bırakılmakta ve Jan Bot'un kendi yapısından kaynaklanan sürpriz tercihlerin ortaya çıkmasına izin verilmektedir. Bunun 
nedeni; Jan Bot'un insani tercihlerden ve klişelerden uzak karmaşık stilinin desteklenmek istenmesidir (Loogman ve Palma, 2018). Filmin oluşturulması aşaması Jan Bot'un "kara kutu" denilen yaratım alanında gerçekleştirilir. Bu alanda görüntüler ve ara yazılar belirlenirken tüm süreç karmaşık ve algoritmik bir kurgu aşamasına dönüşür. "Kara kutu”, Jan Bot'un gerçek yaratııılığını gösterdiği ve kimseye hesap vermek zorunda kalmadığı özgür bir alanı temsil etmektedir. Filmin yayınlanması aşamasında; Jan Bot'un genellikle 20-30 saniye arası süren ve ara yazıların da yer aldığı nihai ürünü Facebook, Instagram ve Twitter üzerinden yayınlanmaktadır. Sosyal medya hesaplarında 17.04.2020 tarihi itibarıyla 600'ün üzerinde film yer almaktadir.

\begin{tabular}{|c|c|c|}
\hline Sosyal Medya Profili & Ilk Yayın Tarihi & Takipçi* $^{*}$ \\
\hline www.facebook.com/janbotfilms/ & 6 Ekim 2017 & 413 \\
\hline www.instagram.com/janbotfilms & 7 Mayıs 2018 & 472 \\
\hline twitter.com/janbotfilms & 15 Mayıs 2018 & 141 \\
\hline
\end{tabular}

Tablo 2: Jan Bot'un Sosyal Medya Profilleri (17.04.2020 itibarıla)*

Son aşama ise filmin izlenmesidir. Jan Bot'un sosyal medyada takipçi sayısı çok fazla olmasa da (bkz. Tablo 2), çeşitli etiketlerin ve güncel trendlerin kullanılması ile filmleri izleyen kişi sayısı takipçi sayısını aşmaktadır. Instagram hesabında yer alan en popüler on filmin izleyici sayısı 1673 ile 75 bin arasında değişmektedir. Jan Bot'un bakış açısıyla yapılmış bu filmler; onun kendi zihninin mükemmel üretimleri olarak okunabileceği gibi, anlamsız ve saçma olarak nitelendirilebilir. Filmlerin sosyal medyada yayınlanması, izleyicilerin geri dönüşleri için bir geri besleme aracı sunmaktadır. Bu yolla filmler çeşitli açılardan analizlere tabi tutulabilir; hermenötik yaklaşımla tercihlerin neden ve nasıl yapıldı $\breve{g}_{1}$ incelenebilir, göstergebilimsel analiz uygulanabilir ya da filmler birer bilmece gibi okunup deşifre edilebilir (Loogman ve Palma, 2018).

\section{Bulgular}

\section{Ortalama çekim süresi}

Ortalama çekim süresi (OÇS); bir filmde yer alan tüm çekim sayılarının toplam süreye bölümüyle elde edilen sayıyı ifade etmektedir. OÇS ilk bakışta kendi başına bir anlam ifade etmiyor gibi görünse de; bu alanda yapılan çalışmalarla bu verinin tutarlı sonuçlar sunduğu görülmektedir. Örneğin; çekim tarihleri 1930 ile 2006 yılları arasında olan 7792 film üzerine yapılan bir çalışmada 1955 yılına kadar uzun çekim sürelerine rastlanmakta, bu tarihten sonra ise bazı istisnalar dışında OÇS'nin tutarlı biçimde düştüğü görülmektedir. 1950'li yıllarda ortalama 10 saniye civarı olan bu oran günümüzde bazı filmlerde 2 saniyenin altına düşmektedir. Bu tercihte teknolojik, kültürel ve anlatısal faktörler rol oynamaktadır. Teknolojik açıdan bakıldığında; Cinemascope ve CGI gibi teknolojilerle efektlerin hız kazanması, dijital sinemayla birlikte film çekiminin ucuzlaması ve kurgunun da kolaylaşması, kesme sayısında artışın daha çok tercih edilir olmasını sağlamaktadır (Salt, 2009: 377-378). Kültürel faktörleri izleyicinin dikkat süresinin düşmesine ve hiperaktivite bozukluğuna bağlayan çalışmalar bulunmaktadır. Anlatısal olarak ise; karakterlerden çok olay akışına dayalı sinema anlayışında basit bir çıkış noktasının tercih edilmesi ve kırılmaların diyalogların olmadığı sahnelerle verilmesi OÇS'nin düşüşünde etkilidir (DeLong, Brunick ve Cutting, 2014: 127).

Jan Bot'un filmlerini yaparken kullandığı görüntüler sinemanın doğuşundan sonraki otuz yıla ait olsa da, filmlerdeki OÇS günümüz aksiyon filmlerinin bile oldukça altındadır. 
Cinemetrics (http://www.cinemetrics.lv/) uygulaması aracılığılla incelenen on filmin süre ortalaması 26,4 saniye, çekim sayısı ortalaması ise 54,8' dir. Bu bağlamda Jan Bot'un filmlerinde OÇS, en düşük 0,32 saniye en yüksek 0,74 saniye olmak üzere ortalama 0,48 saniyedir (bkz. Tablo 3). Yani ortalama olarak Jan Bot saniyede iki çekim kullanarak filmlerini yapmaktadır. $\mathrm{Bu}$ tercih farklı şekillerde yorumlanabilir. Öncelikle Jan Bot, tarihi açıdan eski dönemlere ait olan film görüntülerini birleştirerek oldukça dinamik filmler yaratmaktadır. Trendleri ve etiketleri görüntüleri ile eşleştirirken bazen aynı çekimleri tekrar tekrar kullanmaktadır. Fakat buna rağmen kullandığı çekim sayısı oldukça fazladır ve bu şekilde veri tabanında yer alan görsel-işitsel mirası mümkün olduğunca kullanma hedefini gütmektedir. Filmlerdeki hızlı tempo, OÇS'deki değişimde kültürel faktörlerin etkisini hatırlatmakta ve bununla birlikte bir tutarlılık arz etmektedir. Filmlerin karakter gelişimi ya da hikayenin derinleştirilmesi ile ilgilenmediği, trendler ve etiketler üzerinden görüntüleri mümkün olduğunca efektif biçimde kullanılmasını amaçladığı söylenebilir.

\begin{tabular}{|c|c|c|c|c|c|c|}
\hline No & Konu & Tarih & Görüntülenme* & $\begin{array}{c}\text { Süre } \\
\text { (saniye) }\end{array}$ & $\begin{array}{l}\text { Çekim } \\
\text { Sayısı }\end{array}$ & $\begin{array}{c}\text { Ortalama } \\
\text { Çekim } \\
\text { Süresi }\end{array}$ \\
\hline 1 & Bianca Devins & 16.7.2019 & 75572 & 27 & 70 & 0,38 \\
\hline 2 & $\begin{array}{l}\text { Anders Holch } \\
\text { Povlsen }\end{array}$ & 22.4 .2019 & 37364 & 28 & 59 & 0,47 \\
\hline 3 & $\begin{array}{l}\text { New Zealand } \\
\text { shooter video }\end{array}$ & 16.3 .2019 & 6366 & 26 & 35 & 0,74 \\
\hline 4 & Bachelorette & 9.8 .2018 & 5772 & 28 & 61 & 0,45 \\
\hline 5 & $\begin{array}{c}\text { most liked } \\
\text { Instagram photo }\end{array}$ & 14.1.2019 & 4053 & 29 & 68 & 0,42 \\
\hline 6 & Rebekah Vardy & 9.10 .2019 & 3627 & 27 & 48 & 0,56 \\
\hline 7 & $\begin{array}{c}\text { Iggy Azalea leaked } \\
\text { photos }\end{array}$ & 29.5 .2019 & 2229 & 22 & 67 & 0,32 \\
\hline 8 & Beth Chapman & 24.6 .2019 & 1870 & 24 & 40 & 0,6 \\
\hline 9 & $\begin{array}{c}\text { Saoirse Kennedy } \\
\text { Hill }\end{array}$ & 3.8 .2019 & 1766 & 26 & 45 & 0,57 \\
\hline \multirow[t]{2}{*}{10} & Morgan Freeman & 25.5 .2018 & 1673 & 27 & 55 & 0,49 \\
\hline & & & Ortalama & 26,4 & 54,8 & 0,48 \\
\hline
\end{tabular}

Tablo 3: Filmlerin görüntülenme, ortalama çekim sayıları ve süreleri* (17.04.2020 itibarıyla).

\section{Anlatı yapisı}

Sinemada anlatı yapısı birçok yaklaşıma ve sınıflandırmaya açıktır. En temel düzeyde baktığımızda ise anlatıların üç ya da dört maddeye indirgendiğini görürüz. Anlatı yapısını geleneksel anlatı, çağdaş anlatı ve postmodern anlatı olarak üçe ayıran yaklaşımda geleneksel anlatı; öykünün yükselen bir dramatik eğriye sahip olduğu ve çatışma-doruk nokta-çözülme aşamalarının takip edildiği bir yapıdadır. Çağdaş anlatıda karakterler, olay veya öykünün önüne geçerken somut sorunlar yerine soyut yaklaşımlar ortaya çıkmaktadır. Postmodern anlatıda ise zaman ve mekan yaklaşımı muğlaklaşır, bireysel sorunlardan çok temalar ön plana çıkar. Geleneksel ve çağdaş yaklaşımdan çeşitli unsurlar ödünç alınarak yeni bir biçem yaratılması hedeflenir (Serter, 2008: 35-43).

Jan Bot'un filmlerinin anlatılarının temelinde internetteki günlük trendler ve etiketler yer almaktadır. Doğal dil işlemeye bağlı olarak yaratılan filmler, çıkış noktaları ile anlamsal bir bağ kurmaktan çok onu bir başlangıç noktası olarak görmektedir. Bu yaklaşım avangart 
sinemacılardan Louis Delluc' un "fotojeni" kavramını hatırlatmaktadır. Fotojeni; "film karesini resmedilen nesneden ayıran belirleyici niteliktir." Filmin yaratıcısı bir nesneyi alır ve kendi bakış açısını ona yansıtarak yeni bir anlam yaratır. Benzer şekilde Jan Bot da kelimeleri taramakta, onları görüntülerle eşleştirmekte ve bu görüntüleri arka arkaya dizerek yeni anlamlar yaratmaktadır (Sucu, 2012: 115). Böylece belki de normalde yan yana gelmeyecek iki görüntü, bir araya gelerek yeni bir görsel anlam sunmaktadır.

\begin{tabular}{|c|c|c|}
\hline No & Konu & Trend \\
\hline 1 & Bianca Devins & Instagram fenomeninin öldürülme görüntüleri \\
\hline 2 & Anders Holch Povlsen & $\begin{array}{l}\text { Danimarkalı milyarder Anders Holch Povlsen'in üç çocuğunun } \\
\text { Sri Lanka saldırısında öldürülmesi }\end{array}$ \\
\hline 3 & $\begin{array}{l}\text { New Zealand shooter } \\
\text { video }\end{array}$ & Yeni Zelanda terör saldırısının videosu \\
\hline 4 & Bachelorette & Aynı isimli Reality show sezon finali \\
\hline 5 & $\begin{array}{l}\text { most liked Instagram } \\
\text { photo }\end{array}$ & Instagram'da en çok beğenilen fotoğraf \\
\hline 6 & Rebekah Vardy & $\begin{array}{l}\text { Rebekah Vardy'nin Coleen Rooney'e } \\
\text { ait bilgileri sızdırması }\end{array}$ \\
\hline 7 & $\begin{array}{l}\text { Iggy Azalea leaked } \\
\text { photos }\end{array}$ & Şarkıcı Iggy Azalea'nın ifşa edilen fotoğrafları \\
\hline 8 & Beth Chapman & Reality Show yıldızının ölümü \\
\hline 9 & Saoirse Kennedy Hill & Robert F. Kennedy'nin torununun ölümü \\
\hline 10 & Morgan Freeman & Morgan Freeman'a taciz suçlaması \\
\hline
\end{tabular}

Tablo 4: Jan Bot'un en çok izlenen on filminin konusunu oluşturan trendler.

Jan Bot'un en çok izlenen on filminin konularına bakıldığında (bkz. Tablo 4) genel olarak magazinsel içerikler olduğu gözlemlenmektedir. On filmden sekizi popüler kültür içerisindeki insanlar ve programlarla ilgiliyken iki tanesi terör saldırısı ile ilişkilendirilmektedir. Elbette bu filmlerin izlenme sayılarının fazla olmasının nedeni, filmler sosyal medyada paylaşılırken kullanılan etiketlerdir. Jan Bot'un Instagram hesabını 472 kişi takip ederken Bianca Devins videosunu 75 bin kişi izlemiştir. Bu video için kullanılan \#biancadevins, \#bianca, \#biancadeath, \#biancadevinsdeath, \#biancadevinsdeathphotos, \#biancadeathphotos gibi etiketler internet kullanıcılarını videoya çekmiştir. Böylece filmin anlatı yapısından, içeriğinden ve karakterlerinden çok filmde yer aldığı ima edilen görseller ve isimler izleyici için filmin izlenmesini yeterli kılan unsurlara dönüşmüştür. Elde edilen bu sonuç, güncel trendlerin sinemaya yansıması halinde izleyici potansiyelinin ne olacağına yönelik bir fikir sunmaktadır.

Jan Bot'un imza attığı filmler, "kolaj film" olarak adlandırılabilir. Kolaj film, farklı kaynaklardan alınan görüntülerin art arda dizilmesiyle ya da yeni çekilmiş görüntülerle birleştirilmesiyle oluşturulan bir film tarzıdır (Beaver, 2006: 46). Bu filmler farklı görüntüleri bir araya getirerek yeni hikayeler yaratmayı sağladığı gibi görüntünün ya da parçanın doğasını sorgulama yoluna da gidebilir. 
1930'larda uygulanmaya başlanan ve ilk zamanlarda daha çok bir mizah unsuru olarak değerlendirilen kolaj film tekniği, zamanla film tarihi ve kanonu üzerine bir düşünme pratiğine dönüşmüştür. Dijital sinema kavramı ile birlikte hayatımıza giren veri tabanları, devasa boyutta işlenmemiş halde bulunan görüntü verilerini bir araya getirmektedir. Görüntülerin sahip olduğu anlatım potansiyelleri, yeni anlatıların kurulması için bir fırsat yaratmaktadır (Manovich, 2001: 208).

Wees (1993: 38) özellikle buluntu filmlerin anlam yaratması konusunda iki yaklaşımdan söz etmektedir. Bu yaklaşımlardan ilki; var olan görününün, gerçeği olduğu gibi yansıtması amacıyla kullanılmasıdır. Örneğin; bir kolaj film olan Atomic Cafe (Jayne Loader, 1982) filminde 1946 'da gerçekleştirilen bir atom bombası denemesine yer verilmektedir. Bu görüntünün kullanım amacı; atom bombasının nasıl patladığının gösterilmesidir. Diğer yaklaşım ise kullanılan nesnenin simgeleştirilmesi ve gösterilen haline getirilmesidir. A Movie (Bruce Conner, 1958) filminde de bir atomik patlama görüntüsüne yer verilmektedir. Fakat bu görüntü; birçok farklı görüntüyle kolajlanmıştır. Bir denizaltı derinlere iner, bir subay periskoptan bakar, bir kapak kızı kameraya soyunmaktadır, subay ateş emri verir, torpido ateşlenir ve okyanus suyu patlamayla kabarırken bu dalgada bir sörfçü belirir. Tüm bu görüntülerin kolajlanması, metaforik bir anlam yaratmakta ve yok etme içgüdüsü ile cinsel arzu arasında bir ilişki kurmaktadir.

Benzer bir yaklaşım The Green Fog (Yeşil Sis, Guy Maddin, Evan Johnson E Galen Johnson, 2017) filminde de gözlemlenebilir. Alfred Hitchcock' un Vertigo (Ölüm Korkusu, 1958) filminden yola çıkarak San Francisco kentinin sinema tarihindeki yerine dair diğer filmlerden görüntüleri kolajlayan bu yapımın hemen başında, şehri yeşil bir sis kaplar. Bu yeşil sisin neden olduğu mutasyon, bir bakıma filmin kolaj yapısına ve karmaşık anlatısına bir temel oluşturur. Yönetmenler; film parçalarından bir anlatı oluştururken bir bilimkurgu-korku fantezisini kullanmaktadırlar. Horwatt (2013: 216)'a göre kolaj film; yapısı itibarıyla araçsal bir özellik kazanmakta ve duygusal etki ile görsel güç aracılığıyla birleştirdiği film parçalarını tarihsel bağlamından koparmaktadır. Farklı içeriklerden alınmış özellikler bir araya geldiklerinde melez bir anlatının parçası olmaktadırlar.

Jan Bot'un kolaj filmlerine baktığımızda da benzer bir yaklaşım gözlemlenmekte ve parçalar yeni bir bütün oluşturmaktadır. Jan Bot'un filmlerinde dramatik eğri, çatışma ve çözülme gibi yaklaşımlara rastlanmamakta, karakterler derinleştirilmemekte ve bir bakıma kendilerine ayrılan süre çerçevesinde ekrana yansımaktadırlar. Farklı zaman ve mekanlara ait görüntülerin bir araya gelmesiyle her görüntünün kendine has anlamı, film bütünü içerisinde erimekte ve daha büyük bir anlatının parçası olmaktadır. Bu bağlamda Jan Bot'un filmlerinin anlatı primitif temsil biçimine yakın durmaktadır.

Filmlerle trend olan kelimeler arasındaki en net bağlantı, ara yazılarda karşımıza çıkmaktadır. Ara yazılar bir bakıma filmin konusunu ve çıkış noktasını izleyiciye hatırlatma görevi görmekte ve ilk bakışta anlatıyı bir merkeze oturtma çabasının sonucu olarak düşünülmektedir. Fakat ara yazılarda kuralsız bir İngilizce kullanılması ve cümlelerin eksik ya da düşük yapıları, net bir anlama ulaşma çabasını boşa çıkarmakta ve hatta kelimelerle görüntüleri birleştiren yapının anlaşılmayarak tepki görmesine neden olmaktadır. Örneğin; "Anders Holch Povlsen" videosunun ara yazılarında (bkz. Görsel 1) "Mother Bombing A Journalist" (Bir Gazeteciyi Bombalayan Anne), "Now They Bombing A Funeral" (Şimdi Bir Cenazeyi Bombalıyorlar) ve "And Mother Attacks A Fear" (Ve Anne Bir Korkuya Saldırıyor) cümlelerin yer alması nedeniyle bazı kullanıcılar videonun kaldırılmasını istemiş ya da şikayette bulunmuşlardır. 


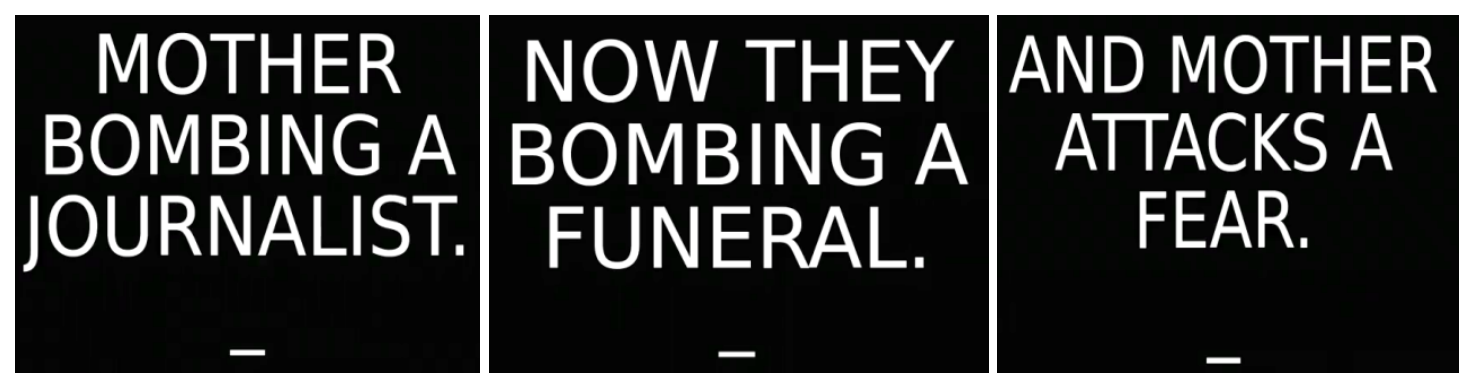

Görsel 1: "Anders Holch Povlsen" filminin arayazılart

Jan Bot'un filmlerinin birçok yoruma açık soyut yapısı, Bordwell (1985: 275-278)'in "parametrik anlatı" adını verdiği yaklaşımı hatırlatmaktadır. Biçem merkezli bu yaklaşımda her sahne birbiriyle bağlantılı gibi görünse de kurgunun zamansal-mekansal manipülasyonu veya çerçevelemenin sonsuz ihtimalleri gibi denemelerle statik bir anlam yaratma çabası reddedilir. Filmler öncelikle görsel ve işitsel yapılardır, fikirler daha sonra dahil olurlar. Jan Bot'un filmleri ise fikirlerden doğsa da algoritmaların sonsuz ihtimaller denizinde o fikirleri yeniden yorumlar, geleneksel ve çağdaş anlatıların anaakım yaklaşımlarını ters yüz eder ve ticari kaygılardan uzak biçimde izleyicilerin beğenisine sunulur.

\section{Sinematografi}

Sinemayı doğuşundan itibaren diğer sanatlardan ayıran özelliği, hareketi kaydetme yetisi olmuştur. Hareketli veya sabit görüntünün kaydedilerek izleyiciye sunulmasında kamera ve sinematografi önemli bir rol oynar. Çeşitli planlar ve kamera hareketli ile anlatılmak ve vurgulanmak istenen anlatısal ve biçimsel özellikler ön plana çıkarılabilir. Uzun metraj bir film birçok plan ve kamera hareketi içerebileceği gibi bazı planlar ve hareketler, o filmin yaratıcısı ile özdeşleştirilebilir. Belirli anlamların vurgulanması için tercih edilen bu hareketler, filmde belirli bir düzende sergilenebilirler.

Jan Bot'un filmlerinin planların ve kamera hareketlerinin analiz edilmesinde Mercado (2011: 44-195)'nun belirlediği on altı plan ve dokuz kamera hareketi temel alınmıştır. 548 planın incelenmesi sonucunda Jan Bot'un en çok genel planları (146 kez) ve ayrıntı planları (136 kez) kullandığ1 tespit edilmiştir. Bunu takip eden planlar ise çerçevede insanların yer aldığı çekimlerdeki göğüs, diz, boy, bel ve baş planlarıdır. Planların analizinde dikkat çeken nokta ise her filmde belirli planların öne çıkması ve vurgulanmış olmasıdır. Örneğin; 3 numaralı "New Zealand shooter video" filminde kullanılan 35 planın $30^{\prime} \mathrm{u}$ genel, 5'i ise baş plandır. 5 numaralı "most liked Instagram photo" filminde yer alan 68 planın 54'ü yine genel planken 6 numaralı "Rebekah Vardy" filminde göğüs planların hakimiyeti göz çarpar. Jan Bot'un tercihlerini şekillendiren ilk unsur şüphesiz ki veri tabanın sınırlamasıdır. Filmlerin ait olduğu dönem düşünüldügüünde planların birçoğu statiktir. Örneğin; öznel ve eğik planlar filmlerde yer almamaktadır. Fakat Jan Bot' un filmlerinde analizde kullanilan 16 plandan en fazla 6 ya da 7 tanesinin yer alması ve bu planlardan iki tanesinin çoğunlukla kullanılan çekimlerin yarısına tekabül etmesi, sinematografik tercihlerde bir tutarlılığ ifade etmektedir.

Filmlerde kamera hareketlerinin analizinde ise oldukça az veri elde edilebilmiştir. 3, 5 ve 9 numaralı filmlerde birer kez pan hareketi tespit edilirken, kameranın sabit kalmasının en önemli nedeni olarak çekimlerin oldukça hızlı biçimde değişmesi gösterilebilir. Jan Bot çekimler için seçtiği görüntüleri uzun süreli kullanmamakta ve farklı planları tercih etmektedir. Kamera sabit olarak kalmasına karşın aksiyon, çerçeve içindeki hareketle sağlanmaktadır. Sonuç olarak; Jan Bot'un filmlerinde planların ve kamera hareketlerinin belirli bir düzen ve tekrar içerisinde gerçekleştiğini söylemek mümkündür.

\footnotetext{
${ }^{3}$ Çevrimiçi, https:/ / www.instagram.com/p/BwkS09ClEaZ/, Erişim Tarihi: 25.04.2020.
} 


\section{Mizansen}

Mizansen; perdeye yansıyan bir filmin sahnelerindeki unsurların tamamını içeren bir terimdir. Mizansenin yapıları; çerçeveleme, dekor, 1şık, kostüm, makyaj ve çekim açıları gibi başlıklar altında incelenebilir. Mizansen bir bakıma; yazılı olan bir senaryonun görsel dünyaya nasıl yansıtılacağı ile ilgilidir.

Jan Bot'un filmlerinde üzerine konuşmanın en zor olduğu biçem unsuru mizansendir. Planların ve kamera hareketlerinin tutarlılığının aksine Jan Bot'un kullandığı çekimlerde çok farklı çerçeveleme, dekor, 1şık, kostüm ve makyaj tercihleri bulunmaktadır. Örneğin; siyahbeyaz, sepya gibi farklı renklere sahip filmler bir arada kullanılmış, çerçeveye alınan görüntüler farklı arka planlardan, coğrafyalardan ve dönemlerden seçilmiştir. 1numaralı "Bianca Devins" filminde konu alınan cinayeti hatırlatan birtakım görüntüler seçilmiştir: Yatakta hareketsiz yatan bir kadın, kovalamaca görüntüsü, ateş eden bir el ve sırtından vurulan bir erkek gibi... Buna karşın filmde verilen genel planlar, bu sahnelerle bağlantısız görünmektedir. 2 numaralı "Anders Holch Povlsen" filmi ise on film içerisinde en tutarlı yapıya sahip olandır (bkz. Görsel 2). Danimarkalı milyarder Anders Holch Povlsen' in üç çocuğunun Sri Lanka'da tatil yaptıkları esnada bombalı saldırıda ölmeleri üzerine hazırlanan bu filmde öncelikle tatilde olan bir kadın görüntüsü verilir. Bu görüntünün sepya renkte olması, bir yaz tatili hissiyatı vermektedir. Sonrasında elindeki silahla ateş eden bir kadının görüntüsü ile " $X$ " simgesi üst üste biner. Siyah beyaz olan bu çekim, tatil çekiminin yumuşak görüntüsünü yok eder. Son görüntüde ise beyazlar içerisinde hareketsiz bir kadın görüntüsü vardır. Bu kadın figürü, ruhani bir çağrışım yapar ve ölenleri hatırlatır gibidir.
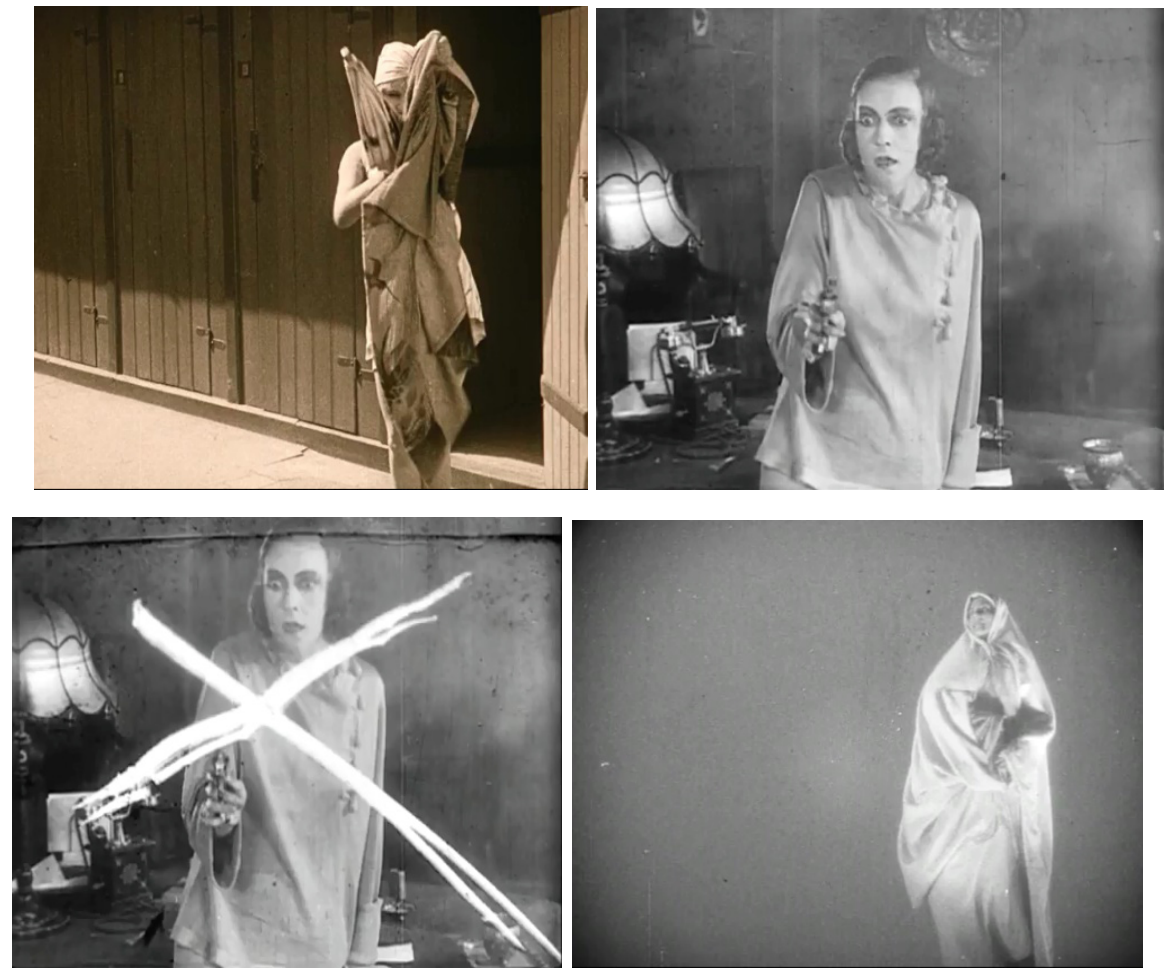

Görsel 2: "Anders Holch Povlsen" filminde mizansen"

\section{Kurgu}

Bir filmin meydana getirilmesinde; çekimlerin, planların, sahnelerin ve sekansların anlamlı ya da yaratıcısının istediği biçimde birleştirilmesi, en önemli aşamalardan birini oluşturmaktadır. Kurgu aşaması da somut bir işlem olarak "kesme"yi, görsel işitsel ögeleri "düzenleme"yi ve planlar arasında bağ kurma amaciyla "kurgu"yu temsil etmektedir (Kücükerdoğan, 2014: 46). Kurgunun filmler üzerindeki etkisi çeşitli başlıklara göre ${ }^{4}$ Çevrimiçi, https://www.instagram.com/p/BwkS09CIEaZ/, Erişim Tarihi: 25.04.2020. 
incelenebilmektedir. Söz konusu Jan Bot'un filmleri olduğunda ise tekrar eden bir düzenden söz etmek mümkün olmaktadır.

Zamansal ve mekansal açıdan Jan Bot'un filmleri paralelleştirilen kurgu ${ }^{5}$ başlığı altında incelenebilir. Anlatısal ve nedensel amaçların aksine paralelleştirilen kurguda ardı ardına kurgulanan sahneler arasındaki birleşim noktaları muğlaktır. Her çekim kendi bütünlüğü içerisinde var olur ve eylemler arasındaki ilişki ön planda değildir. Jan Bot'un farklı içeriklerden bulduğu ve birleştirdiği görüntüler çoğunlukla ana temaya hizmet etseler de nadiren bir devamlılık ve anlamlı bütünlük içerisindedir. Biçimsel açıdan ise filmlerde belirli sahnelerin ardı ardına ya da belli aralıklarla tekrar ettiği göze çarpmaktadır. ${ }^{6}$ Trend olan kelimeleri işleyerek veri tabanındaki görüntülerle birleştiren Jan Bot'un bazı görüntülerde ısrarcı olması, tematik anlamda o sahnelerin yapay zekanın mantığı içerisinde tam bir temsil gücü olmasıyla ilgilidir. Jan Bot'un anlatımı dünyayı ya da hikayeyi keşfetmeye çıkmamakta, başkasının yaptığı gözlemleri yeni bir bakış açısıyla keşfetmektedir. Filmler bir konu hakkında olmaktan çok kendileri hakkındadırlar. Filmler hayatın kendisinden veya ana temalarından soyutlanarak kendi iç dünyalarını yaratmaktadırlar.

Kurguyu oluşturan en önemli unsurlardan bir diğeri ise geçiş türleridir. Geçişler ile çekimlerin birbirine bağlanmaları sağlanır. Böylece filmin ritmi önemli ölçüde belirlenmiş olur. Jan Bot'un filmleri geçiş türleri açısından zenginlik sunmaktadır. En çok karşımıza çıkan geçiş türü "kısa kesme"lerdir. Jan Bot çeşitli görüntülerin çok küçük parçalarını birbirine ekleyerek filmlerini oluşturmaktadır. Bu yaklaşım; düzenli ve akıcı bir bakış açısından ziyade izleyiciyi sarsan, yoran ve şoka uğratan bir yapıya sahiptir. Bir bakıma Jan Bot'un sinemayı anlama ve kurgulama çabasının bir dışavurumu olarak nitelendirilebilir. Filmlerde ayrıca zincirleme geçişlere, iki görüntünün bindirilmesine, donmalara rastlanmaktadır. Bu geçişler genellikle görsel açıdan farklılık yaratmakla birlikte zaman zaman ana temaya uyumluluk göstermektedir (bkz. Görsel 3).
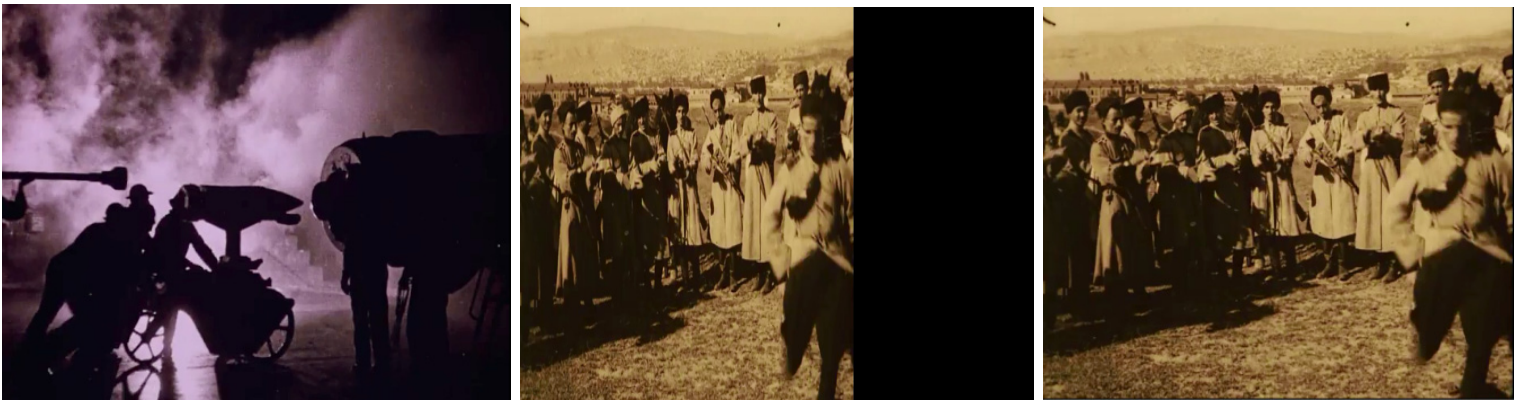

Görsel 3: "New Zealand Shooter Video" başlıkl filmde askerlikle ilgili görüntüler kesme yoluyla art arda verilmektedir. ${ }^{7}$

\section{Ses}

Sinemanın doğuşunda yer almayan bir unsur olan ses, ilk başlarda film esnasında canlı müzik yapılmasıyla ya da ara yazıların okunmasıyla film deneyiminin bir parçası olmuştur. 1920 'lerin sonunda sinemaya tamamen dahil olmaya başlayan ses, dramatik yapının oluşturulmasında önemli bir rol üstlenmiştir. Jan Bot'un tüm filmlerinin ortak özelliği, sessiz olmalarıdır. Bu açıdan sesin bu filmlerin anlatısına ya da biçimsel özelliklerine olan etkisini incelemek mümkün olmamaktadır. Jan Bot'un kullandığı veri tabanının sinemanın ilk otuz

\footnotetext{
${ }^{5}$ Küçükerdoğan (2014: 66); paralel kurgunun yanısıra paralleştirilen kurgudan söz etmektedir. Paralel kurgu “aynı anda gelişmekte olan iki ya da daha fazla olayın film örgüsü içerisinde belli ve ilginin en çok yükseldiği noktaya kadar koşut olarak yürütülmesi" olarak tanımlanırken paralelleştiren kurguda birbirine paralel kurgulanan eylemler hiçbir zaman aynı noktada birleşmemektedir. Paralelleştirilen kurguda hedeflenen şey iki eylemin birleştirilmesi değil, eylemlerin sınırlarla birbirinden ayrılmasıdır.

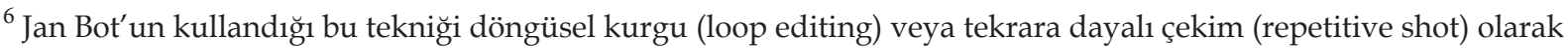
adlandıran kaynaklar bulunmaktadır (Meinich, 2010; Neroni, 2016: 142). Bahsi geçen kaynaklarda bu tekniğin kullanımı; genel olarak çekimde gösterilen karakterin ya da yönetmenin düşüncelerinin somutlaştırılması ile ilişkilendirilmektedir.
}

${ }^{7}$ Çevrimiçi, https:/ / www.instagram.com/p/BvFIWHhFFXH/, Erişim Tarihi: 25.04.2020 
yılına ait olması, sesin yokluğunu anlamlı bir hale getirmekte ve belki de yapay zekanın arşiv görüntülerine müdahale etmediği tek alan olarak öne çıkmaktadır.

\section{Sonuç}

$\mathrm{Bu}$ çalışmada Jan Bot adı verilen bir film yapım robotunun eserleri sinema biçemi açısından değerlendirilmiştir. Jan Bot'u benzersiz kılan unsur; yaratıcılığa yol açan doğasının belirsizliği ve bir bakıma hesap verme ya da kendini açıklama zorunluluğundan muaf oluşudur. İncelenen filmler, makinelerin ve insanların düşünce biçimleri arasındaki farkın görsel bir ifadesine dönüşmektedir. Jan Bot'un popüler etiketlerden ve trendlerden esinlenerek film yaratması anaakım bir yaklaşım sunarken; kendi mantığında yarattığı benzersiz biçemi, avangart yaklaşımlar doğrultusunda sinemanın doğasını keşfetmeye, onu yıkmaya ve yeniden inşa etmeye yönelik çabaları hatırlatmaktadır. Primitif temsil biçimini hatırlatan bu yaklaşım, sıfır noktası yaklaşımının sınırlayıcı etkilerini ortadan kaldırmakta ve yapay zekanın yaratıcı yönünü vurgulamaktadır. Elbette bu çıkarım yapılırken sinema endüstrisinin yapay zekasinema birlikteliğini, kurumsal temsil biçimini destekleyecek bir ütopyanın başlangıç noktası olarak gördüğü unutulmamalıdır.

On film üzerine yapılan biçemsel analiz sonucunda birçok başlıkta tutarlı sonuçlar elde edilmiştir. Jan Bot' un anlaşılması zor filmlerinin arkasında, anlamlı ve düzenli tekrarlara dayalı tercihlere rastlanmaktadır. Bu bağlamda yapay zekanın kişisel biçem tercihleri üzerinden biçimci uca daha yakın olduğu söylenebilir. Anlatı yapısı olarak postmodern ve parametrik anlatılara yakınlık tespit edilmiştir. Popüler temalar bir başlangıç noktası olarak alınmış ve algoritmaların süzgecinden geçirilerek fotojenik bir yaklaşımla yeniden yorumlanmıştır. Çekim sürelerinin kısa tutulmasıyla izleyicinin filmi algılayış biçimi etkilenmiş; kameranın sabitliğine karşın aksiyon, çerçeve içinde sunulmuştur. Böylece sinemanın ilk yıllarındaki kamera hareketleri ile 21. yüzyılın ortalama çekim süreleri sentezlenmiştir. Mizansen tercihlerinde veri tabanının sinırlılıkları fazlasıyla hissedilmekte ve Jan Bot'un tercih mantığı ilk üç başlığa göre daha belirsiz kalmaktadır. Kurgu aşamasında ise paralelleştirilen kurgu yaklaşımı tespit edilmektedir.

Sanat epistemolojisi çerçevesinde sanatçı ve sanat eseri arasındaki ilişki söz konusu olduğunda ise Jan Bot'un çabasının ilk bakışta insan eylemlerini taklit etmekten öteye gidemediği söylenebilir. Pratik manada Jan Bot elindeki görüntüleri kendi prensipleri doğrultusunda bir araya getirmekte ve bu işi sürekli yaparak deneyim kazanmaktadır. Veri tabanındaki filmleri yeniden birleştirmekte ve kullandığı içeriklerin üretim süreçlerini çözümleyerek kendi film yapım modeline yansıtmaktadır. Biçemsel tercihlerindeki tutarlılık bu açıdan mantık çerçevesine oturmaktadır. İçeriksel anlamda baktığımızda ise filmlerin klasik anlatı prensiplerinin dışına çıkması, rasyonel anlayışın ötesinde bir yapıyı işaret etmektedir. Veri tabanına olan bağlılıktan dolayı Jan Bot belirli kodların ötesine geçememektedir. Bu nedenle de ortaya çıkan ürünün bilinçli bir üretim ya da sanatçının imzası olarak görülmesi doğru olmayacaktır. Jan Bot'un gösterdiği formel estetik, var olan film parçalarının belirli bir süzgeçten yansımasını sağlamaktadır. Bu bağlamda ortaya çıkan eserin bir film olduğu ama onu yaratanın bir film yönetmeni olmadığı söylenebilir. Jan Bot'un ya da gelecekte sayıları artacak olan film robotlarının kendi duygulanımlarını veya düşüncelerini eserlerine aktarıp aktaramayacağı veya bu aktarım gerçekleşse bile insanların zihin ve duygu süzgecinden geçip geçemeyeceği bir problem olarak varlığını korumaktadır. Fakat yapay zeka tarafından belirli eserlere ait parçaları birleştirme ve buradan yaratıcı bir hareket oluşturma düşüncesi sanatsal alanda etkisini artırdıkça, modern sanat çerçevesinde kaynak aldığ sanatçıya benzer tarz geliştirip yeni eserler üretme anlayışı estetik beklentileri karşılayan yepyeni bir bakış getirecektir. Şimdilik Jan Bot'un film yapmayı "düşlemediği" ya da biraz daha ileri gidersek, çeşitli biçemsel tercihlerine rağmen yaratıcı (auteur) yönetmen olamadığı söylenebilir.

$\mathrm{Bu}$ çalışmanın ötesinde; ilerde yapay zeka uygulamaları tarafından üretilen filmlerin 
izleyici tarafından nasıl algılandığına yönelik alımlama çalışmalarının yapılması, yapay zekanın sinema endüstrisinde başarılı olabilecek filmler için "yeşil 1şık" yakmasının monokültür kavramı içerisinde şablonlaşma tehlikesi yaratıp yaratmayacağı gibi sorunların işlenmesi, alan için faydalı olacaktır.

\section{Kaynakça}

Akbay, B. (2015, Ekim). Deniz Yılmaz (Blog yazısı). Erişim adresi: https:// bagerakbay.com/ deniz-yilmaz/

Anadolu, B. (2019). Dijital Hikaye Anlatıcılığı Bağlamında Yapay Zekanın Sinemaya Etkisi: Sunspring ve It's No Game Filmlerinin Analizi. Erciyes İletişim Dergisi, (1), 39-56. doi: 10.17680/ erciyesiletisim. 483510

Avcıoğlu, A. (2017). Algoritmaların Savaşı. Arka Pencere Mecmua, 1, 110-111.

Balc1, F. (2019). Epistemolojik Bir Problem Olarak Sanat Eseri. Journal of Arts, 2(1), 1-15. doi: $10.31566 /$ arts.2.001

Beaver, F.E. (2006). Dictionary of Film Terms: The Aesthetic Companion to Film Art. Peter Lang Publishing.

Biçem. (t.y.). Türk Dil Kurumu güncel Türkçe sözlük içinde. Erişim adresi: http:/ / www.tdk.gov. tr/

Bordwell, D. (1985). Narration in Fiction Film. Madison: University of Wisconsin Press.

Bordwell, D. (1997). On The History of Film Style. Cambridge: Harvard University Press.

Bordwell, D., Thompson, K. (2008). Film Art: An Introduction. New York: McGraw Hill.

Broeckmann, A. (2016). Machine Art in the Twentieth Century. Massachusetts: MIT Press.

Burch, N. (1981). Theory of Film Practice. New Jersey: Princeton University Press.

Burch, N. (1990). Life to those Shadows. Berkeley: University of California Press.

Carter, J. (2018, 12 Ocak). How artificial intelligence is creating new ways of storytelling (Blog yazıs1). Erişim adresi: https://www.techradar.com/news/how-artificial-intelligence-iscreating-new-ways-of-storytelling

Casetti, F. (2011). Sinemasal Deneyim. (D. Kırmızı, Çev.). sinecine, 2(2), 81-93.

Cinemetrics. (2020). Movie Measurement and Study Tool Database. Erişim adresi: http:// www.cinemetrics.lv/

Clark, L. (2015, 25 Şubat). DeepMind's AI is an Atari gaming pro now (Blog yazısı). Erişim adresi: https://www.wired.co.uk/article/google-deepmind-atari

Culkin, N. (2008). Digital Cinema: No Country for Old Entrepreneurs?. Journal of Retail Marketing Management Research, 1(2), 44-58.

DeLong, J. E., Brunick, K. B., Cutting, J.E. (2014). Film Through the Human Visual System: Finding Patterns and Limits. J.C. Kaufman, D.K. Simonton (Der.). The Social Science of Cinema. (s. 123-138). New York: Oxford University Press.

Doğrucan, M.F., Hazar, Z. (2019). Yapay Zeka çalışmalarında Dilsel Arka Plan ve Felsefe. Pamukkale Üniversitesi Sosyal Bilimler Enstitüsü Dergisi,34,159-167.doi:10.30794/pausbed.402424

Encyclopedia Britannica. (2020). Database. Erişim adresi: https://www.britannica.com/ technology/database 
Ganz, A., Khatib, L. (2006). Digital cinema: The transformation of film practice and aesthetics. New Cinemas: Journal of Contemporary Film, 4(1), 21-36. doi: 10.1386/ncin.4.1.21/1

Getlein, M. (2009). Living with Art. New York: McGraw-Hill Education

Giannetti, L. (2014). Understanding Movies. New York: Pearson.

Goffey, A. (2008). Algorithm. M. Fuller (Der.). Software Studies: A Lexicon. (s. 15-20). Massachusetts: MIT Press.

Graham, B. (2014). New Collecting: Exhibiting and Audiences after New Media Art. Surrey: Ashgate.

Gürkan, H. (2016). Yeni Medya ve Sanat İlişkisi: Sinemanın Dönüşümü. Akdeniz İletişim, 25, 161-179. doi.org/10.31123/akil.438539

Horwatt, E. (2013). On the Clock and Christian Marclay's Instrumental Logic of Appropriation. Framework: The Journal of Cinema and Media, 54(2), 208- 225.

Kaplan, A., Haenlein, M. (2018). Siri, Siri, in my hand: Who's the fairest in the land? On the interpretations, illustrations, and implications of artificial intelligence. Business Horizons, 2019, 62, 15-25. doi: 10.1016/j.bushor.2018.08.004

Kirilenko, G., Korshunova, L. (1987). Felsefe Nedir. (G. Aysu, Çev.). İstanbul: Bilim ve Sanat Kitapları.

Küçükerdoğan, B. (2014). Sinemada Kurgu ve Eisenstein. İstanbul: Hayalperest Yayınevi.

Loogman, B., Palma, P.N. (2018). Jan Bot Press Kit (Blog yazısı). Erişim adresi: https://www. jan.bot/press-kit.pdf

Luger, G. F., Stubblefield, W. A. (1998). Artificial Intelligence: Structures and Strategies for Complex Problem Solving. Massachusetts: Addison Wesley Longman.

Manovich, L. (2001). The Language of New Media. Massachusetts: MIT Press.

Matthau, C. (2015, Ocak). How Tech Has Shaped Film Making: The Film vs. Digital Debate is Put to Rest (Blog yazısı). Erişim adresi: https://www.wired.com/insights/2015/01/howtech-shaped-film-making

Meinich, K. (2010, 19 Kasım). Cléo de 5 à 7 (Blog yazısı). Erişim adresi: https://montages. no/2010/11/flashback-cleo-de-5-a-7

Mercado, G. (2011). Sinemacının Gözü: Sinemada Kompozisyon Kuralların Kullanmayı (ve yıkmayı) Öğrenmek. (S. Taylaner, Çev.). İstanbul: Hil Yayın.

Neroni, H. (2016). Feminist Film Theory and Cléo from 5 to 7. New York: Bloomsbury.

Nilsson, N. J. (1998). Artificial Intelligence: A New Synthesis. Massachusetts: Morgan Kaufmann.

Nilsson, N. J. (2010). Yapay Zeka: Geçmişi ve Geleceği. (M. Doğan, Çev.). İstanbul: Boğaziçi Üniversitesi Yayınevi.

Olesen, C. (2013, 8 Kasım). Found footage photogénie: An interview with Elif Rongen-Kaynakçi and Mark-Paul Meyer (Blog yazısı). Erişim adresi: https://necsus-ejms.org/found-footagephotogenie-an-interview-with-elif-rongen-kaynakci-and-mark-paul-meyer/

Palma, P.N. (2018, 29 Kasım). Jan Bot's step by step (Blog yazıs1). Erişim adresi: https:// medium.com/janbot/jan-bots-step-by-step-822b831d0402

Paul, C. (2007). The Database as System and Cultural Form: Anatomies of Cultural Narratives. V. Vesna (Der.). Database Aesthetics: Art in the Age of Information Overflow. (s. 95-110). Minneapolis: University of Minnesota Press.

Penha R., Carvalhais, M. (2019, 18 Haziran). If machines want to make art, will humans understand it? (Blog yazısı). Erişim adresi: https://aeon.co/ideas/if-machines-want-to-make- 
art-will-humans-understand-it

Plaugic, L. (2017, 27 Ağustos). Musician Taryn Southern on composing her new album entirely with AI (Blog yazısı), Erişim adresi: https:/ / www.theverge.com/2017/8/27/16197196/tarynsouthern-album-artificial-intelligence-interview

Prelinger, M. (2015). Inside The Machine: Art and Invention in the Electronic Age. New York: WW. Norton \& Company.

Quaranta, D. (2013). Beyond New Media Art. Brescia: LINK Editions.

Russell, S.J., Norvig, P. (1995). Artificial Intelligence: A Modern Approach. New Jersey: Prentice Hall.

Salt, B. (2009). Film Style and Technology: History and Analysis. London: Starword.

Say, C. (2018). 50 Soruda Yapay Zeka. İstanbul: Bilim ve Gelecek Kitaplığı.

Searle, J. R. (1980). Minds, brains, and programs. Behavioral and Brain Sciences, 3 (3). 417-457. doi: 10.1017/S0140525X00005756

Serter, S. (2005). Sinemada Biçem: Lütfi Ömer Akad Sineması (Yayımlanmamış doktora tezi). Anadolu Üniversitesi, Eskişehir.

Shoemaker, N. (2016, 24 Mart). Japanese AI Writes a Novel, Nearly Wins Literary Award (Blog yazıs1). Erişim adresi: http://bigthink.com/natalie-shoemaker/a-japaneseai-wrote-a-novelalmost-wins-literary-award

Smith, J. R. (2016, 31 Ağustos). IBM Research Takes Watson to Hollywood with the First Cognitive Movie Trailer. Erişim adresi: https://www.ibm.com/blogs/think/2016/08/ cognitive-movie-trailer/.

Stam, R. (2000). Sinema Teorisine Giriş. (S. Salman, Ç. Asatekin, Çev.). İstanbul: Ayrıntı Yayınları.

Style. (t.y.). Merriam-Webster online dictionary içinde. Erişim adresi: https://www.merriamwebster.com/dictionary/style

Sucu, İ. (2012). Sanat Akımlarının Etkisinde Sinemada Klasik ve Alternatif Eğilimler. Akdeniz İletişim, 17, 111-125.

Taşdelen, D. K. (2012, 12 Eylül). Sanat Epistemolojisi (Blog yazıs1). https://demettasdelen. wordpress.com/2012/09/12/sanat-epistemolojisi/.

Taylor, G. D. (2014). When the Machine Made Art: The Troubled History of Computer Art, New York: Bloomsbury.

Tribe, M., Reena, J. (2006). The Last Avant-garde (Blog yazıs1). Erişim adresi: https:/ / rhizome. org/community/38025/

Turing, A. M. (1950). Computing Machinery And Intelligence. Mind A Quarterly Review of Psychology And Philosophy, No. 236. 433-460. doi: 10.1093/mind/LIX.236.433

Ülger, E. (2013). Platon'un Sanat Kuramının Düşünsel Evrimi. FLSF (Felsefe ve Sosyal Bilimler Dergisi), 2013 Güz, sayı:16. 15-28. ISSN: 1306-9535

Wees, William C. (1993). Recycled Images: The Art and Politics of Found Footage Films. New York: Anthology Film Archives.

Youngblood, G. (1970). Expanded Cinema. New York: P. Dutton \& Co. Inc.

Zambak, A. F. (2018). Free Will and Artificial Intelligence. MetaZihin, 1(2), 167-181. ISSN: 26512963

\section{Filmler}

Conner, B. (Yönetmen) (1958). A Movie [Film]. ABD. 
Goodwin, R. (Yapımc1), \& Sharp, O. (Yönetmen). (2016). Sunspring [Kısa Film]. ABD: End Cue.

Goodwin, R. (Yapımcı), \& Sharp, O. (Yönetmen). (2017). It's No Game [Kısa Film]. ABD: End Cue.

Goodwin, R. (Yapımc1), \& Benjamin. (Yönetmen). (2018). Zone Out [Kısa Film]. ABD: End Cue. Hitchcock, A. (Yapımc1) \& Hitchcock, A. (Yönetmen). (1958). Vertigo [Film]. ABD: Alfred J. Hitchcock Productions.

Maddin, G., Johnson, E. \& Johnson, G. (Yönetmen). (2017). The Green Fog [Film]. Kanada \& ABD: Development Ltd.

Rafferty, K., Loader, J. \& Rafferty, P. (Yapımc1) \& Loader, J. (Yönetmen). (1982). The Atomic Cafe [Film]. ABD: Scott Free Productions.

Scott, R., Schaefer, M., Huffam, M. (Yapımc1) \& Scott, L. (Yönetmen). (2016). Morgan [Film]. ABD: Scott Free Productions. 